
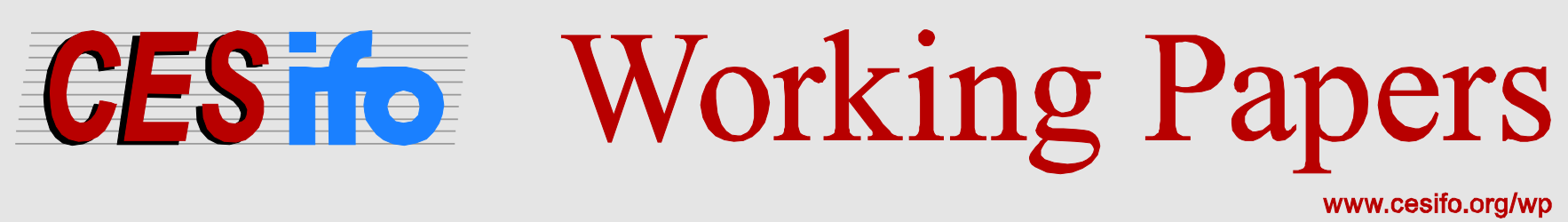

\title{
Longevity Risk and Taxation of Public Pensions
}

\author{
Jukka Lassila \\ Tarmo Valkonen
}
CESIFO WORKING PAPER NO. 5640
CATEGORY 1: PUBLIC FinANCE
DECEMBER 2015
An electronic version of the paper may be downloaded
- from the SSRN website:
- from the RePEc website:
- from the CESifo website: wWw.SSRN.com
Www.RePEc.org
www.CESifo-group.org/wp




\title{
Longevity Risk and Taxation of Public Pensions
}

\begin{abstract}
We study transitions from EET tax regime to TEE regime in a defined-benefit pension scheme with a numerical overlapping generations model, using stochastic mortality projections as inputs. In a traditional pension scheme with no automatic longevity rules, such as a link between life expectancy and pensions or retirement age, the tax regime shift can be used to improve public finances, when longevity increases. Diminished private saving and weaker labour supply incentives are among the downsides. Especially the latter makes the reform welfare-reducing, if the improvement in state finances is not used to relieve taxation of labour.
\end{abstract}

JEL-Codes: H550.

Keywords: taxation, pensions, longevity.

Jukka Lassila

Research Institute of the Finnish Economy

ETLA

Finland - 00120 Helsinki

jukka.lassila@etla.fi
Tarmo Valkonen

Research Institute of the Finnish Economy

ETLA

Finland - 00120 Helsinki

tarmo.valkonen@etla.fi

$30^{\text {th }}$ November 2015

We thank Viktor Steiner and other participants of the Cepar CESifo Workshop on Taxation of Pensions and Niku Määttänen for useful comments. The study was Funded by the European Commission’s Seventh Framework Programme FP7-SSH-2012-1/No 320333. 


\section{Table of Contents}

Longevity risk and taxation of public pensions

Fehler! Textmarke nicht definiert.

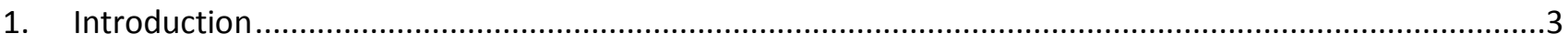

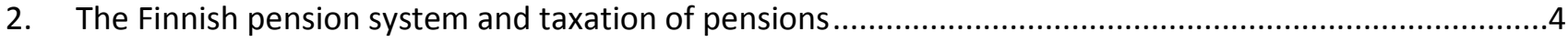

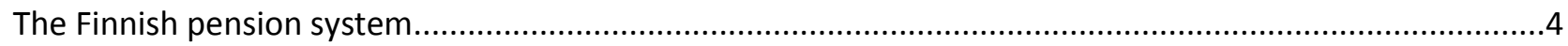

Taxation of a pay-as-you-go financed defined benefit pension scheme .................................................5

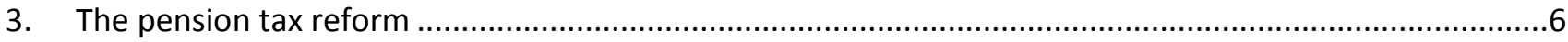

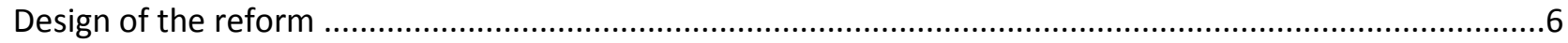

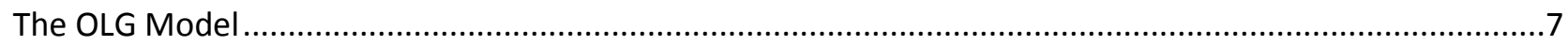

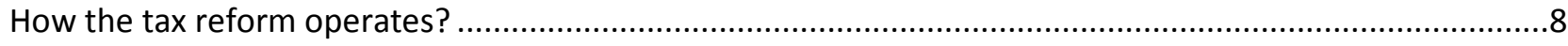

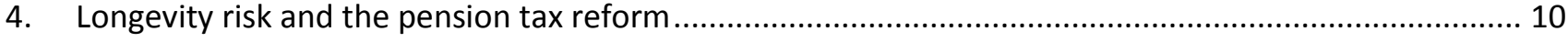

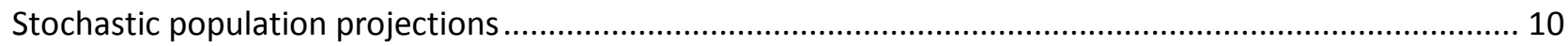

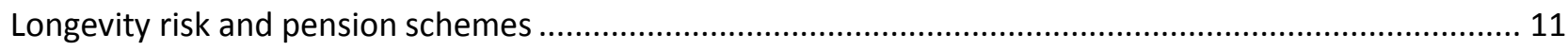

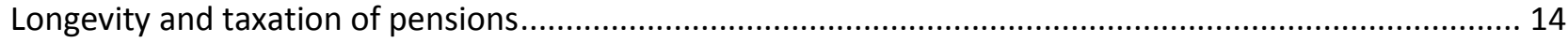

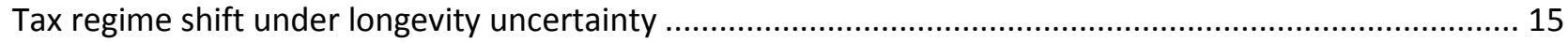

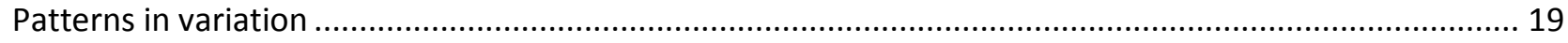

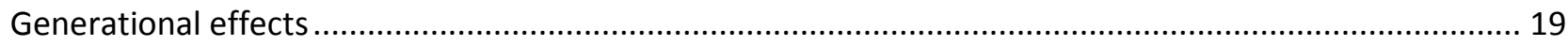

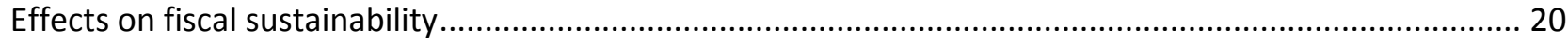

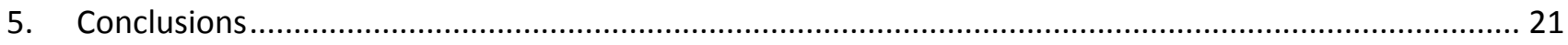

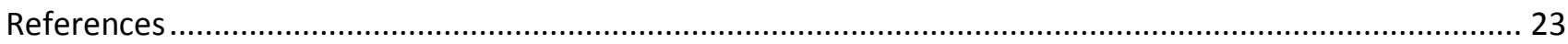

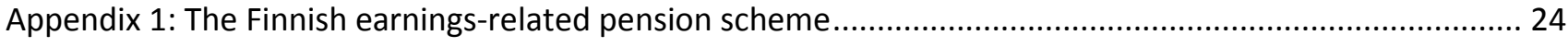

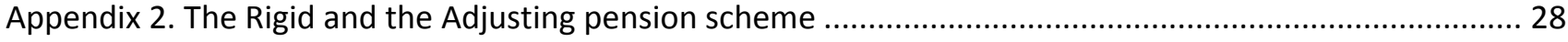




\section{INTRODUCTION}

The decline of mortality rates has concentrated in recent decades to old age. This development has caused severe financing problems for typical public pension schemes, which are based on PAYG financing and defined benefit principle. Continuous increase in the pension contribution rate is not considered a viable solution due to its negative influence on labor supply. Moreover, the growth in longevity has often exceeded predictions, and the needed future increase in the contribution rate is not well known due to the uncertainty related to future mortalities.

The recent pension reforms have introduced two ways out of this problem. The first, life expectancy adjustment of monthly pensions, is the more well-known and largely in use in NDC pension schemes. The risk in this adjustment is that it may endanger the adequacy of pensions. Therefore it has been emphasized that people should recognize this risk and react to it by working longer. But the experience from Sweden, where life expectancy adjustment has affected benefits since 2001, shows that providing information about future pensions is not adequate response for the problem. Therefore a Swedish committee suggested that also the lowest eligibility age for pensions should be linked to life expectancy (SOU, 2013). Finland has decided to introduce this kind of two-way link to life expectancy in its statutory earnings-related pension scheme from the year 2017.

It is common that saving for old age is tax-favored. The aim of tax allowances is to avoid the cumulative distortions of capital income taxation, to compensate for the restricted liquidity and to promote long-term saving of short-sighted individuals (see, for instance, Diamond, 2009). The currently most often used rules of long-term saving are based either on the EET (exempt-exempt-taxed) or TEE (taxed-exempt-exempt) principle.

Longevity affects both the development of pension expenditure, which is the tax base under EET but is not under TEE, and the development of pension contributions which are deductible under EET but not under TEE. The details of the pension scheme determine how strong these links are.

We illustrate the connections between pension tax regimes, longevity, and pension policies using the Finnish earnings-related first pillar pension scheme as an example. Currently the tax regime is EET. We study how a gradual switch to TEE would affect the economy, public finances, firms and households representing various birth cohorts in the future where longevity is likely to increase and pension policies may or may not take this increase into account. We also study how longevity risks are shared between household generations and between the pension scheme and taxpayers in the two tax regimes.

Our analysis combines three branches of previous literature. The first consists of studies that use stochastic population projections as inputs in economic models in order to simulate the influence of pension policies on intergenerational risk sharing and public finances under demographic uncertainty, see e.g. articles in Alho et al. (2008). We have also exploited recent pension policy papers, which simulate different options to adjust public pension schemes to higher longevity, see e.g. Fehr, Kallweit and Kindermann (2012), Sánchez Martín (2010), 
Staubli and Zweimüller (2013) or Lassila, Määttänen and Valkonen (2014). The results point out the efficiency of increasing the eligibility ages for old age pensions and early retirement benefits both in terms of improved public finances and higher retirement income. The third group of relevant papers analyses taxation of fully funded second or third pillar pension schemes. For example, Kudrna and Woodland (2012) simulate a transition from current flat rate taxation to either the EET or the TEE taxation regime in the Australian superannuation pension scheme. The idea is to limit the adverse intragenerational redistribution of the current tax rules. Fehr and Habermann (2008) study the savings and growth effects of introducing a new EET taxed private pension saving scheme. The reason for introducing the scheme is to increase private saving to compensate the expected decline in the replacement rates of public pensions.

Our paper is most related to Chen et al. (2014), who study intergenerational risk sharing. The policy options are changes in pension contribution rates, indexation and taxes. The restrictions are set in terms of min and max public debt and the solvency of the pension fund. The pension fund investments are risky. In the EET taxation regime government participates in sharing the investment risk the more there is room for debt to change. The individuals can also benefit from risk premium, but the tax rates may vary more. In the TEE regime the government can reduce the debt, but earns only the risk-free rate on this operation. Therefore a regime shift is not preferred.

We describe the main features of the Finnish pension system and discuss the principles of pension taxation in Section 2, and then describe and analyze the tax switch around a base demographic projection in Section 3. Tax switch aspects related to future longevity, and how the pension schemes react to longevity, are considered in Section 4. Section 5 concludes.

\section{THE FINNISH PENSION SYSTEM AND TAXATION OF PENSIONS}

\section{The Finnish pension system}

The first pillar of the Finnish pension system consists of the means-tested national pension, the complementary guarantee pension and a statutory earnings-related pension. In addition to providing old age pensions, the system covers also risks related to disability and death of family earners.

The flat rate national pension and the guarantee pension provide a minimum income in cases where the earnings-related pension is insufficient. Access to the national pension requires that a person has lived three years in Finland after turning 16 and access to the guarantee pension a permanent residence. The eligibility age for full pension is 65 years. The pension expenditure was $1.2 \%$ of GDP in 2014. These pensions are taxfinanced.

In the earnings-related scheme every year's earnings affect the future pension without a ceiling. Earliest eligibility age to old age pensions is 63 , but pensions accrue at an accelerated rate until age 68 , if they are not 
withdrawn while working ${ }^{2}$. After turning 68 no new pension rights are accrued, but a yearly increase is applied if withdrawal is deferred. Also a longevity adjustment is applied to pensions. The size of the adjustment is calculated by comparing the observed life expectancy of the cohort at age 62 to the average of that number from years 2003-2007. A tight link between earnings and benefits ${ }^{3}$ and the longevity adjustment of pensions imply that even though the pension scheme follows defined benefit principle it reacts to earnings risks and longevity risks much like a defined contribution scheme. The scheme has collected substantial funds to smoothen the contribution increases due to population ageing. The size of the pension expenditure was $11.9 \%$ of GDP in 2014 and the size of the prefunded amount was $84 \%$ of GDP at the end of year 2014. Taxation of the earnings-related pensions applies EET principle. The tax regime supports the scheme rather strongly due to the highly progressive taxation of the earned income.

The lack of a pension ceiling in the earnings-related scheme explains why voluntary group pensions financed by the employer and individual pensions have a limited role in Finland. Contributions to these schemes amounted only to $0.4 \%$ of GDP in 2014. The total sum of the accrued funds was $8.6 \%$ of GDP at the end of 2014.

Voluntary pensions are taxed following EET principle. The group pensions are taxed as earned income. The tax deductions of individual pension contributions are calculated using the almost flat capital income tax rate and the pensions are taxed as capital income. The maximum yearly contributions eligible for this capital income tax regime is 5000 euros. Contributions above the ceiling are taxed applying partial TET principle, which in practice has ruled out single-premium pension insurances. Significant increases in the lowest eligibility age and the transition from earned income tax regime to less generous capital income tax regime have reduced heavily the popularity of individual pensions.

\section{Taxation of a pay-as-you-go financed defined benefit pension scheme}

Taxation of fully funded defined contribution pension schemes provides saving neutrality, if certain conditions are met. The neutral tax regimes are TEE, EET and TtE. The last mentioned regime involves no deduction of contributions, no tax on riskless rate of return (rate-of-return allowance) and no taxes on pensions. These regimes are identical if the tax rates applied to deductions and pensions are same and if there are no risks related to the rate of return. Even if the pension funds are invested in risky assets, EET and TtE regimes can generate identical outcome, if the saved deductions in EET regime are invested in riskless assets. In that case government participates in sharing the yield risk and receives as a reward positive expected tax revenues. If the deductions are invested in risky assets, outcomes of TEE and EET regimes become identical and the government does not participate in sharing of the yield risk.

Incentives to saving are not relevant to mandatory pay-as-you-go pension schemes, but it is illustrative to discuss lifetime neutrality of the tax regimes also in this context. The commonly used EET tax regime is not neutral for several reasons. The tax rates applied to deductions and pensions are different and the implicit yield of the pension contributions is on average below the yield of saving. In case of employees' contributions, the

\footnotetext{
2 The labour market parties have agreed on a reform that increases the lowest eligibility age of old age pensions from year 2018 gradually by two years and links it thereafter to life expectancy. The same increases in access ages will be applied also in the early retirement schemes.

${ }^{3}$ Actually, means-testing of the national pension and the pensioner's housing supplement against earnings-related pensions weaken the link between earned income and pensions. But this kind of implicit taxation is common also in countries which apply DC pension schemes,
} 
disparity between tax rates applied are due to the progressivity of earned incomes and possibly also because of specific rules applied in the taxation of pensions. If the employee invests the money saved due to the tax deduction to financial markets, she is likely to get higher return on her contributions in EET than in the TEE regime, where there is no deduction, but pensions are tax-free.

Interaction between employers' contributions and tax revenues is more complicated. The contributions can be deducted from taxable profits in EET regime. If the incidence of the deduction is on labour, deductibility lowers labour costs allowing higher wages and increased employment. Even if the government loses corporate income tax revenues due to EET, it receives more earned income taxes higher since the total wage bill is larger. As far as the incidence of the deduction is on capital, government receives less corporate income tax revenues, but more capital income tax revenues from the owners of the firms, because after-tax profits are higher due to the deduction.

In short, the employees benefit the more on EET regime the higher is the employees' contribution rate, the higher is the marginal tax rate of wages related to the marginal tax rate of pensions and the larger is the difference between yield of saving and the implicit yield of the DB pension scheme. As far as the incidence of the deduction is on labour, the benefit from EET is the bigger the higher is the employers' contribution rate and corporate income tax rate ${ }^{4}$. The tax relief improves incentives to supply labour, but weakens redistributive effects of progressive taxation. Since EET is likely to reduce tax revenues, the final incidence depends also on the way how government balances its budget.

\section{THE PENSION TAX REFORM}

\section{Design of the reform}

In the Finnish earnings-related pension scheme, all paid work increases the individual's future pension. Thus the monthly benefit is a sum of accruals from different work years. We assume a gradual move from EET to TEE regime where, in the future, those parts of pension benefits that are based on accruals from 2013 onwards will not be taxed. Benefits based on accruals before 2013 are taxed, yielding tax revenues until all pensioners that have even a small accrual from pre-2013 years are dead.

Earnings-related pensions are financed by pension contributions, paid by both employers and employees. Under the current EET taxation, employer contributions are accepted as expenses when corporate taxes are set, and employee contributions can be deducted from wage income when income taxes are calculated. In the gradual move from EET to TEE regime we assume that contributions that finance pension benefits based on accruals from 2013 onwards will not be tax deductible, whereas contributions financing benefits based on accruals before 2013 are deductible. There is thus generational tax consistency in the tax switch: If benefits are taxed, the contributions that finance such benefits are tax deductible, and if benefits are not taxed, the corresponding contributions are not tax deductible.

\footnotetext{
${ }^{4}$ The size of the deduction is $t^{*} l^{*} w L$, where $t$ is corporate income tax rate, $l$ is employers' pension contribution rate
} and $w L$ is total wages. 
Generational tax consistency has different implications for different types of pension systems. In a fully funded pension system a gradual move from EET to TEE regime would be generationally tax consistent in the above sense, if benefits based on contributions paid from the switch date onwards become tax-free and tax deductibility of contributions is removed in the beginning of the switch. The reason is that future contributions are used to finance future pension accruals only. In a pay-as-you-go financed system generational tax neutrality requires a more complicated treatment of contributions, because future contributions are used to finance benefits based on both old accruals and new accruals.

Whereas EET can be described as 'postponed taxation' when the pension system is fully funded, it could be described as 'postponed deductions' when pay-as-you-go financing is applied. This may sound counterintuitive, as all contributions have been tax deductible from day one of the PAYG pension system. But one can think of PAYG system as a fully funded system that has debt (and a different inner yield). The debt has accumulated because there has been 'missing contributions', and when the debt is paid by a part of future contributions, the deductions can be carried out. NDC-systems usually show this debt explicitly. The debt may never be fully paid, it is just rolled over, but specific parts of the debt are related to individual pension rights and they are fully paid when the individual ceases to receive benefits.

The Finnish earnings-related pension scheme is partially funded, partially PAYG. In the switch from EET to TEE, contributions that are funded for future benefits based on accruals from 2013 onwards cease to be tax deductible, as in a fully funded system. Contributions that finance the PAYG part of benefits will be tax deductible if benefits are based on accruals before year 2013, and not deductible otherwise.

The quantitative effects of the tax switch will obviously depend on how the population ages and how the pension scheme copes with population ageing. In this Section we assume that future demographics follow Statistics Finland's 2012 population forecast. Life expectancies are predicted to grow also in the future. As noted earlier, longer lifetimes would increase pension expenditure unless some pension policy measures prevent this. Two popular measures have been automatic benefit adjustment and higher eligibility ages. In Finland the first is in use since 2010: longevity adjustment, based on observed mortalities, of future monthly benefits is done when the cohort reaches the age of 62 . The second measure is included in the forthcoming 2017 reform, where the earliest old-age retirement age is gradually raised to 65 and, after 2029, linked to life expectancies.

For the pension scheme, we consider two extremes. Rigid pension scheme is a traditional DB, where there is neither longevity adjustment of benefits nor longer work careers when people live longer. This was the case in Finland before 2005. Adjusting pension scheme has both longevity adjustment of benefits and longer work careers which are partially due to a link between retirement age and longevity, as in Finland after 2017. Otherwise, both pension schemes follow the rules of the current statutory Finnish earnings-related pension scheme with some minor exceptions (see Appendix 2).

\section{The OLG Model}

The population projection is used as an input in an economic model. We use a perfect foresight numerical overlapping generations model of the type originated by Auerbach and Kotlikoff (1987). It is modified to describe a small open economy and calibrated to the Finnish economy. The FOG model consists of five sectors and three markets. The sectors are households, enterprises, a government, two pension funds and a foreign 
sector. The labor, goods and capital markets are competitive and prices balance supply and demand period-byperiod. There is no money or inflation in the model. The unit period is five years, and the model has 16 adult generations living in each period. The model is described in more detail e.g., in Lassila and Valkonen (2007).

The driving forces of the model economy are the transitions in the demographic and educational structure of the population and the trend growth of labor productivity. Population is ageing due to longer lifetimes, low fertility rates and the transition of baby boomers from working age to retirement.

Labor input is determined partly by exogenous assumptions and partly due to endogenous adjustments in the model. Exogenous factors are trend growth of labor productivity, demographic trends, educational gains and unemployment rate. Real wage adjusts to equalize the value of marginal product of labor and labor costs in the production of private goods and services. The rest of the workers, who provide tax-funded services produced in private and public sector, earn the same wage.

Public expenditures have strong connection to the age of individuals. Provision of public services is allocated mainly either to the early part of the life cycle (day care and education) or to the last ten years (health care and old age care). Similarly, income transfers are distributed mainly either to young families or to retired individuals. This is why the changes in the demographic structure are so important. We assume that all income transfers (except the earnings-related pensions) are fully indexed to wages because any other assumption would have dramatic consequences to income distribution in the very long term analysis. Other than agerelated expenditure is assumed to grow at the same rate as the GDP.

The modeled main subsectors of the general government, such as the municipal sector, the public and the private sector pension fund and the national social security institute, have their own budgets, which are balanced either by social security contributions or earned income taxes. The only exception is the state budget, which is balanced by a lump sum tax/transfer. Earned income tax brackets are adjusted with the growth of the economy. The pension funds follow their current prefunding plans, and pension contributions are endogenous. Households react to the income and substitution effects of taxation and social security contributions. The current rules of the earnings-related pension scheme are described in detail in Appendix 1.

\section{How the tax reform operates?}

We first discuss the main mechanisms that are expected from the tax reform. As described above, the simulation model includes detailed description of the subsectors of the Finnish public sector and the main rules of taxation and social security, which complicates the results somewhat, but also brings them closer to reality. The quantitative effects are influenced also by the fact that Finland is a Nordic welfare state, which uses lot of tax revenues to finance the extensive provision of income transfers and public services. The regime shift described below has been implemented assuming that the Rigid pension scheme is in place.

\section{Firms and labour market}

Firms pay a major share of the pension contributions, in case of Finland around 18 percent of wages, compared to the employee's 6 percent. These employers' contributions become after the reform gradually nondeductible in the corporate income taxation, which currently applies flat tax rate of 20 percent. Abolishing the deductibility of contributions would therefore initially reduce net profits by 3,6 percent of wages and increase 
by the same amount the tax revenues of the public sector. As the after tax marginal productivity of the labour input falls, also demand for labour and wages fall.

\section{Households}

For households, the tax reform means that the average and marginal tax rates of wages becomes gradually higher and the tax rate of pensions declines eventually to zero. Since the first effect is larger, lifetime taxation of labour income will tighten. Since also the wages decline, the incentives to work weaken and the households supply less hours. Saving decreases significantly because the after tax income diminishes during working life and increases during the retirement years.

\section{Local and central government}

For public finances, the net outcome consists of three elements. First is the increase in tax revenue due to tightening of taxation. Second is a decrease in tax revenue because of smaller incomes and consumption. Third is the decline in public expenditure due to lower wage rate, which cuts down the public sector labour costs and income transfers indexed to wages.

The local government (municipalities) taxes earned incomes with a flat rate. The abolishment of the deductibility of employees' pension contribution increases revenues from taxing wages, but the reduction in the wage bill and abolition of tax on pensions scales down the tax revenues. The municipalities also receive part of the increased corporate income tax revenues from the government. On the expenditure side the fall in the wages and pensions of the public sector workers supports the finances. It turns out that the negative effects dominate and the municipalities have to raise somewhat the income tax rate to balance the budget.

The central government taxes earned income with a strongly progressive scale. Therefore the abolishment of the deduction of the employees' contribution rate has now much larger effect. The positive effect of the tax reform on the earned income tax revenues is amplified by the fact that the average state tax rate on pensions is low. Approximately $70 \%$ of pensioners do not pay in practice any state tax on their pensions in Finland. Central government collects also a major share of the strongly increasing revenues from the corporate income tax. These factors outweigh the negative influence of abolished tax on pensions, smaller wage bill and profits, less saving and reduced consumption on tax revenues. The overall improvement in the state revenues allows a reduction in the lump-sum tax that is used in the simulations to balance the state budget.

\section{The earnings-related pension scheme}

The tax regime shift influences also the pension scheme, but not very much under our assumption that the rules determining the size of benefits are not changed even though pensions become tax free. The decrease in the wage rate lowers earned pension rights and also index adjustments of the accrued pension rights and the pensions. Therefore pension expenditure diminishes. On the other hand, the smaller wage bill reduces the amount of contribution revenues raised. Therefore no large changes in the contribution rate are expected.

\section{To sum up:}

How all this can be wrapped up? The tax reform succeeds in improving public finances, but with a cost of lower wages, employment, private consumption and household wealth. A measure which reduces lump-sum taxation and increases taxation of wages and corporate incomes weakens the efficiency of the economy and is likely to cause a welfare loss. 
Table 1.

\begin{tabular}{|c|c|c|c|c|c|}
\hline \multicolumn{5}{|c|}{ Effects of the tax regime shift, rigid pension scheme } & \multirow[b]{2}{*}{ Long run } \\
\hline & 2023 & 2043 & 2063 & 2083 & \\
\hline Wage, $\%$ & -4.65 & -4.60 & -4.35 & -4.33 & -5.6 \\
\hline Private employment, \% & -0.10 & -0.52 & -1.39 & -2.00 & -1.2 \\
\hline Household wealth, \% & -7.17 & -19.05 & -28.85 & -36.14 & -52.0 \\
\hline Private consumption, $\%$ & -0.68 & -0.97 & -1.60 & -2.69 & -6.2 \\
\hline Public expenditure/GDP, pp & -0.89 & -1.01 & -0.94 & -0.86 & -1.0 \\
\hline Total taxes/GDP, pp & -0.24 & -0.16 & 0.49 & 0.82 & 0.6 \\
\hline
\end{tabular}

The general equilibrium price effects in the almost small open economy are rather limited. Interest rate does not rise even though saving falls, which restricts the decline in investments. Domestic production diminishes somewhat due to the negative labour supply reaction, but since the private consumption reduces even more, equilibrium in the markets of the domestic good requires a fall in the producer price.

\section{LONGEVITY RISK AND THE PENSION TAX REFORM}

To illustrate and quantify the tax regime shift effects with uncertain longevity, we simulate what happens in the Finnish economy when mortality differs from what is expected in Statistics Finland's 2012 population projection. We use the OLG model jointly with stochastic mortality simulations.

\section{Stochastic population projections}

We deal with demographic uncertainty by using such stochastic population projections. Statistical methods of expressing demographic uncertainty have been developed by many researchers (see e.g. Alho and Spencer, 2005). These methods quantify uncertainty probabilistically, based on analyses of past demographic data and the views of experts. Fertility, mortality and migration are considered as stochastic processes. The parameters of these processes are fitted to match the errors of past forecasts (see Alho et al., 2008). Thereafter, sample paths for future population by age-groups are simulated. Stochastic population projections are produced by a computer program PEP. As a descriptor of the length of life, we use period life expectancy at 30, average of males and females. We express it as total life expectancy, that is, 30 years plus the remaining life expectancy at 30. During the next fifty years this life expectancy is expected rise to an unprecedented level in Finland. It is, however, very hard to say exactly how high this level is. That is why we resort to stochastic simulations, which are based on statistical analysis of past demographics and forecast errors. We cite Alho (2002): "The analysis of uncertainty was based on the relative error of the naive forecast with data for 5-year age-groups for 19001994. In the case of mortality, the naive forecast assumed that the recent past decline in mortality continues indefinitely. As discussed in Alho (1990) and Lee and Miller (2001), the naive method and related extrapolation methods perform typically equally well as (or better than!) the judgmental official forecasts." 
Figure 1 shows the predictive distribution of the total life expectancy at 30 for the next 50 years. The median increases by 7.5 years. The $50 \%$ probability interval is about 3.5 years wide in 2060s, and the width of the $80 \%$ interval is 7 years. The predictive distribution is calculated from a stochastic population projection produced by Juha Alho in 2013 by a computer program PEP ${ }^{5}$. This stochastic projection is built around Statistics Finland's 2012 projection.

For our OLG model analysis, we first make a constant-mortality version the 2012 population forecast. The constant-mortality population starts from the age structure in the beginning of 2013 and assumes a constant inflow of persons below 20 years of age in the future, no net migration, and the 2012 age-specific mortalities in all future periods. This population evolves so that new young generations are all of the same size, and the cohorts diminish in time by the constant mortality rates.

In the alternative population paths, we start from the constant-mortality projection but allow future mortalities to deviate from those. These deviations follow the assumptions used in the stochastic population projection. We use 500 simulated population paths which differ only due to different mortality developments.

Figure 1. Predictive distribution of total life expectancy at 30 in Finland

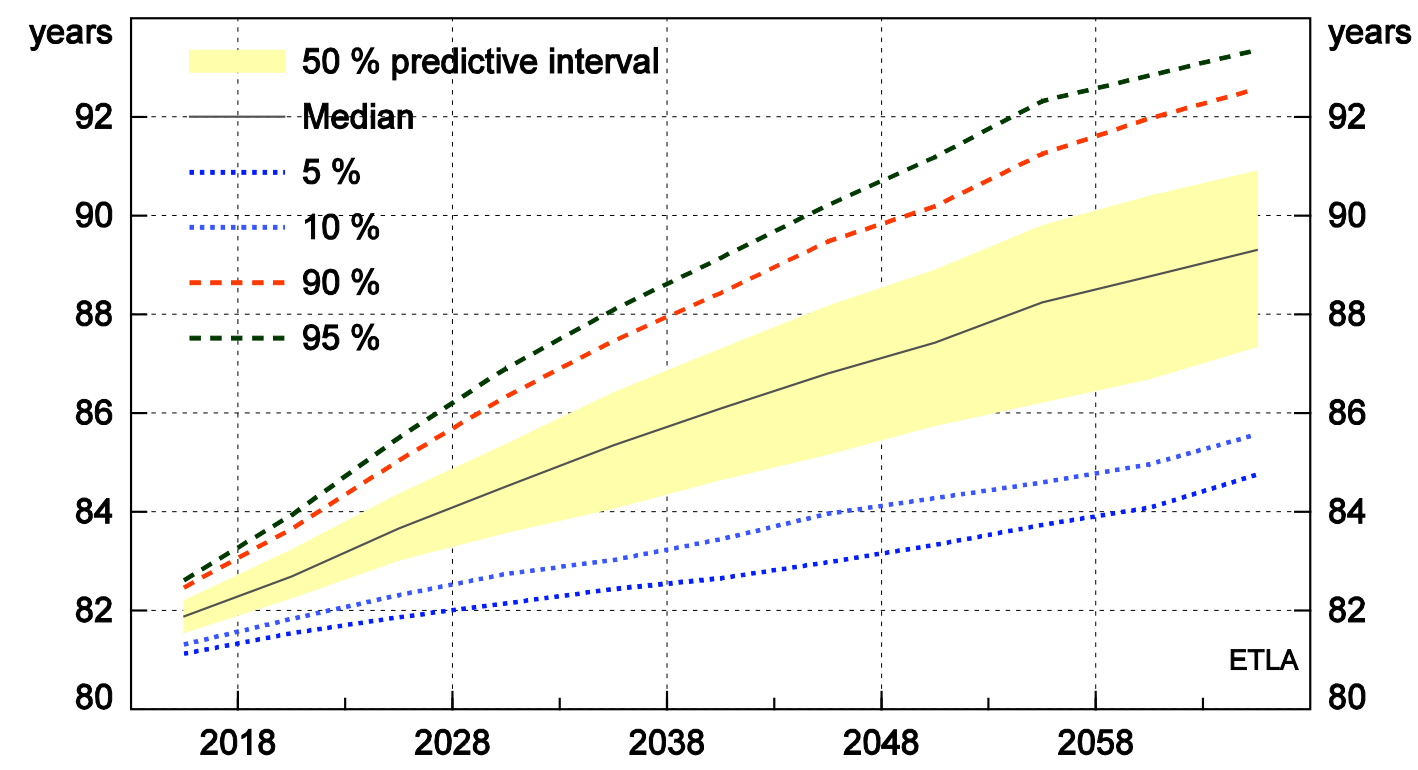

\section{Longevity risk and pension schemes}

According to the estimates of Niku Määttänen (2014), an additional 3 years to the life expectancy of a 30-yearold would extend working lives by 6 months, assuming that any health problems are likewise postponed by 3 years. This information has been used in the FOG model in such a way that the change in life expectancy automatically affects the length of working lives at the ratio depicted, even if pension rules were unchanged.

\footnotetext{
${ }^{5}$ For a probabilistic interpretation of stochastic population simulations, visit
} http://www.stat.fi/tup/euupe/sf interpretation.html. 
Linking retirement age to life expectancy, as in the Adjusting scheme, affects the length of working lives. Based on the model used by Määttänen (2014), raising the eligibility ages of the pensionable age, the unemployment pathway and the part-time pension by two years would extend working lives by 7 months. Extending working lives are included in the FOG model, starting in 2018 exogenously through the pensioner proportion, since the model does not contain labour supply decisions in the extensive margin.

We illustrate the interaction of pension schemes and uncertain life expectancy in EET tax regime. Figure 2 shows how the pension contribution rate rises with future longevity under Rigid pension scheme but stays flat under Adjusting pension scheme. The outcomes are created with FOG model. Each dot represents one realization of the 500 stochastic mortality projections.

Figure 2. Pension contribution rate in 2063-67 with varying longevity

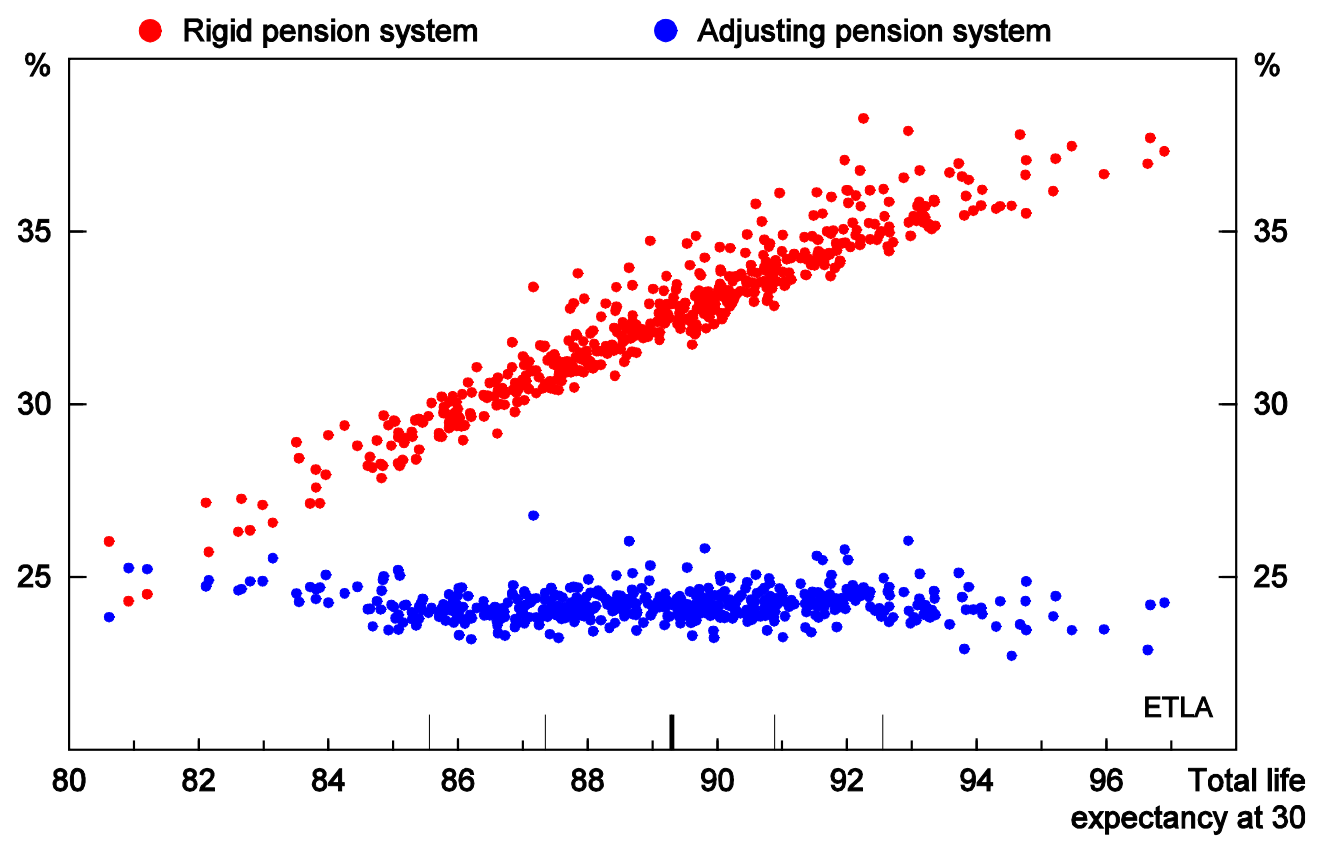

Figure 3 depicts a similar pattern for pension expenditure relative to wage bill, except that under Adjusting scheme there seems to be a slight negative trend. Longevity is measured in both figures by the total life expectancy of a 30-year old in 2063-67. 
Figure 3. Pension expenditure, \% of wage bill, in 2063-67 with varying longevity

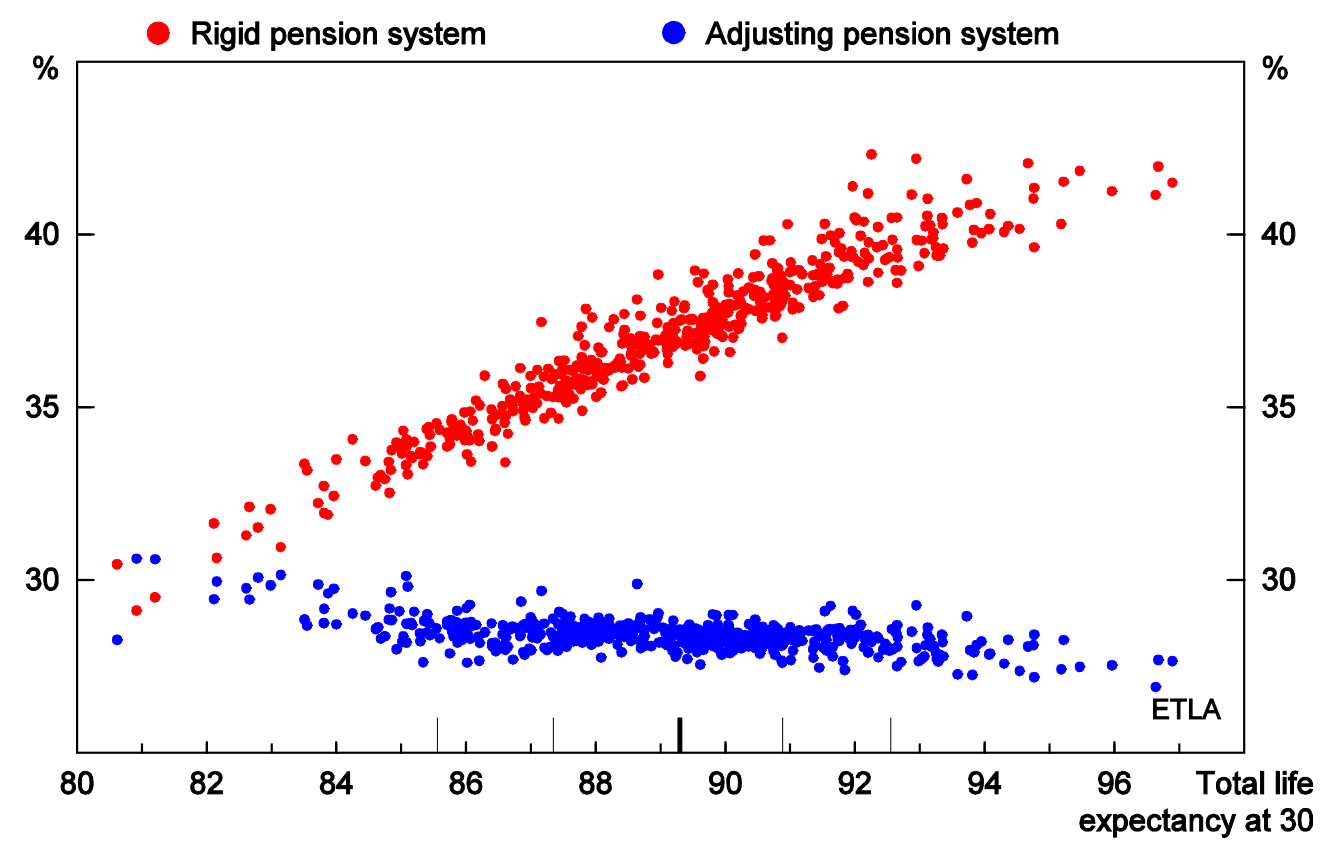

If lifetimes become continuously longer, the contribution rate in the Rigid pension scheme is too low to finance the future pensions of the current working age generations, because it is based on realized pension expenditure and mortality rates. The Adjusting pension scheme aims to allocate the higher expenditure to right generations. The allocation is not perfect, because it is based on life expectancy near the retirement age, which does not consider the changes in the mortality rates during the retirement years.

Households react to longer lifetimes by working more and saving more for old age. The scale of the reactions depends strongly on the details of the pension scheme. The higher pension contributions in the Rigid scheme lower wages. Thereby it also reduces incentives to work and the ability to save for old age. The lower pensions and higher retirement age in the Adjusting scheme extends working lives and increase saving for old age. The substantial increase in working hours has negative effect on wages, but private consumption can still be sustained at considerably higher level. Also the public finances are more resilient against lower mortality rates. 
Figure 4. Labour supply (ind. 2013=1), in 2063-67 with varying longevity

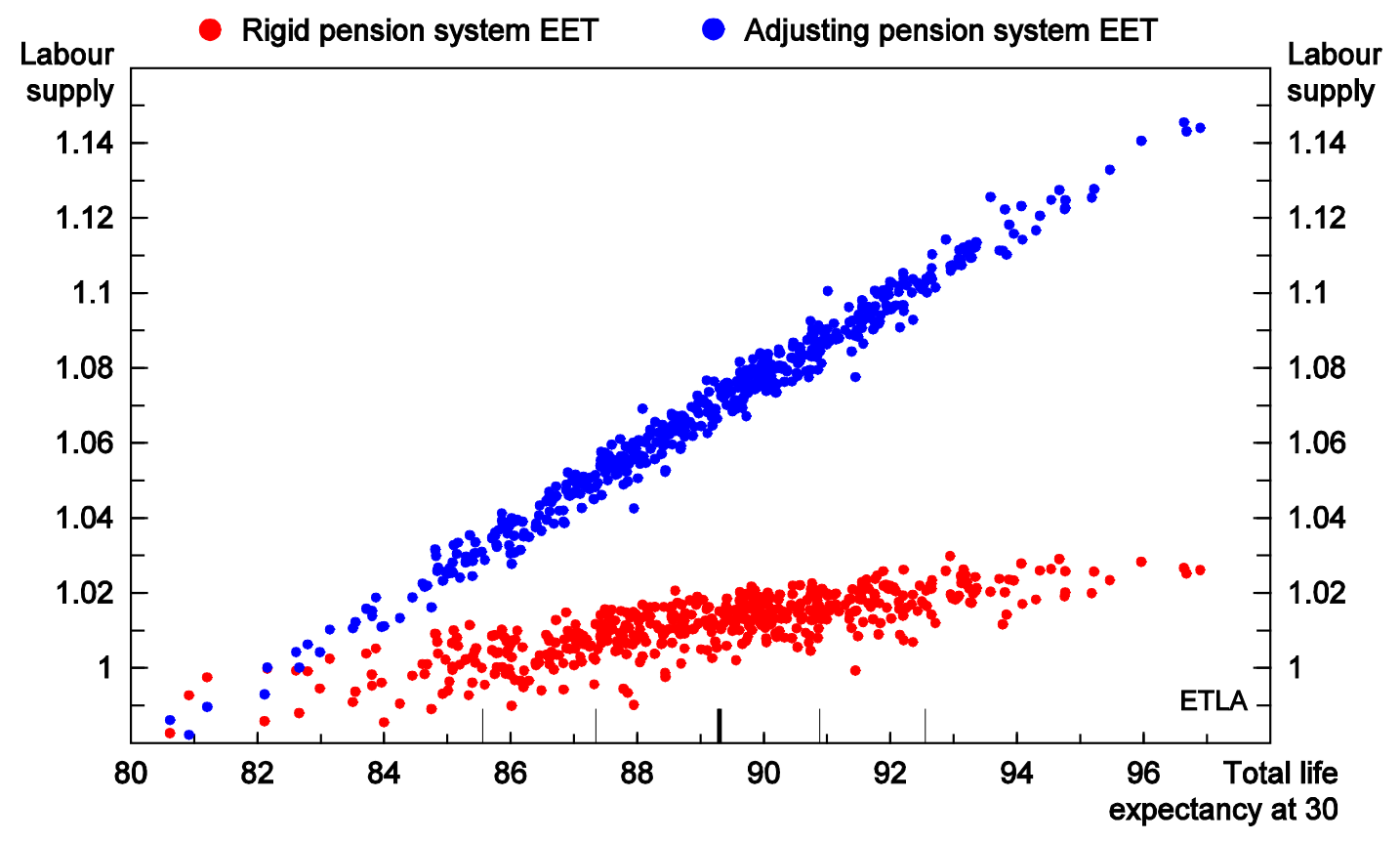

\section{Longevity and taxation of pensions}

\section{Rigid pension scheme}

As noted above, longer lifetimes increase number of pensioners, and in the Rigid pension scheme also pension expenditure and contribution rates. The tax revenues of the general government decline because of the lower wages.

If the taxation of the pension scheme follows EET rules, the tax deductions from wages and profits will be larger, which enhances the loss in the tax revenues. Even though the amount of taxed pensions is larger, there will be a drop in overall tax revenues. In TEE regime the higher contributions due to longer lifetimes are not deductible, which limits the direct loss in tax revenues. On the other hand, the wages and profits fall more.

\section{Pension scheme adjusted to longevity}

Adjusting pensions to life expectancy means that the accrued pension rights are divided at the time of the retirement by the expected number of retirement years. The monthly benefit is the lower the more life expectancy has increased. On the other hand, the needed increase in contribution rate is also smaller. With this kind of adjustment sharing of longevity risk in a DB pension scheme operates like in a DC scheme.

If longevity adjustment is applied in EET regime, higher life expectancy does not generate as much taxable pension income, but also the needed increase in the contribution rate is smaller as well as the deductions of the contributions from taxable wages and profits. The public finances are less sensitive to longer lifetimes also in the TEE tax regime, since the fall in wages and profits due to higher contributions are small. 
Adjusting the eligibility age for old age pensions to life expectancy operates in another way, but the beneficial public finance outcomes are comparable. Longer lifetimes increase strongly labour supply. The larger tax base for pension contributions together with the reduced retirement years diminishes the pressure to increase the contribution rate generated by longer lifetimes. The choice of the tax regime becomes again less important.

In the studied Adjusting pension scheme both the pension benefit and retirement age adjustments to higher life expectancy are in use. The life expectancy adjustment has, however, been moderated to avoid an excessive cut in the ratio of paid contributions and received benefits.

\section{Tax regime shift under longevity uncertainty}

\section{Rigid pension scheme}

We simulate a surprise policy reform in which the new employees' and employers' contributions of the rigid DB pension scheme are not any more deductible in taxation and new accrued pension rights are tax-exempt. The old pension rights will still be taxed as soon as they are realized as paid pensions. This reform is simulated 500 times using different realizations of the stochastic mortality projection. The results are shown in Figures 5 and 6 and in Table 2.

Shifting the taxation of pensions from retirement years to working years has profound impacts on the decisions of the households and the public finances. Moreover, in the Rigid pension scheme these impacts are the bigger the longer are the lifetimes. This is because the main driver of the tax reform results, which is the amount of pension contributions to be deducted in taxation, is directly linked to length of the retirement period.

The Finnish earnings-related pension scheme is mainly financed by employers' contributions, which means that a major share of the labour market adjustments depends on the incidence of corporate taxes and the contributions. As the economy is small and open, the incidence is mostly on labour.

The second large driver is the reduced need to save for old age after the tax reform. The interaction with longevity is now different. The longer the lifetimes are the more people save. Therefore, the amount of additional saving needed is cut by the tax reform more strongly in high longevity scenarios.

The third marked driver of the results is the tightening of labour income taxation, which is the stronger the longer the lifetimes are. There is a need for the households to work the more the longer are the retirement periods, but taxation distort increasingly the decisions.

Figures 5 and 6 show the effects of the regime shift on public expenditure and total taxes. This tax measure does not include the lump-sum tax used to balance the state budget. The policy reform has consistent influence in the Rigid pension scheme. The higher the life expectancy, the higher is the tax rate, even though also public expenditure diminishes. The main effect is due to increasing pension contributions, which cannot be deducted in income taxation after the reform. Public expenditure decline more in the high longevity scenarios because the tax regime shift cuts public sector wages more.

\section{Adjusting pension scheme}

In the second set of simulations the tax reform has been implemented in an economy, which has longevity adjustments in the earnings-related pension scheme. 
Since the pension scheme largely neutralizes the influence of longer lifetimes on contributions, the role of taxation in risk sharing weakens. There is no jump in the pension contribution rate and the corresponding increase in deductions if longevity increases. But the regime shift itself still increases the labour costs of firms and lowers wages. There will also be a considerable decline in private saving, wealth and consumption, but they are still markedly smaller than in the case of Rigid scheme.

In the Adjusting pension scheme, the individuals compensate for the fall in monthly pensions, caused by longer lifetimes, by working and saving more. Therefore also the private consumption can remain at higher level. The links between longevity, pension contributions and public sector wages are much weaker and the public finances are more resilient against longevity risks. In other words, from the point of view of public finances, the longevity adjustments in pensions and retirement age seems to serve as substitute for a transition from EET to TEE regime.

Transition of the aggregate longevity risk from contributions to benefits reduces variation in the deducted amount, but increases variation in the revenues from taxing pensions. The overall variation in the net tax revenues under longevity uncertainty is smaller in the Adjusting scheme than in the Rigid scheme as well as the role of the government as a sharer of the aggregate longevity risk. The overall results in the TEE regime are similar, since the contribution rate does not react much in the Adjusting pension scheme.

Figure 5. Tax switch effects on total taxes/GDP, \%, in 2063 - 67 with varying longevity

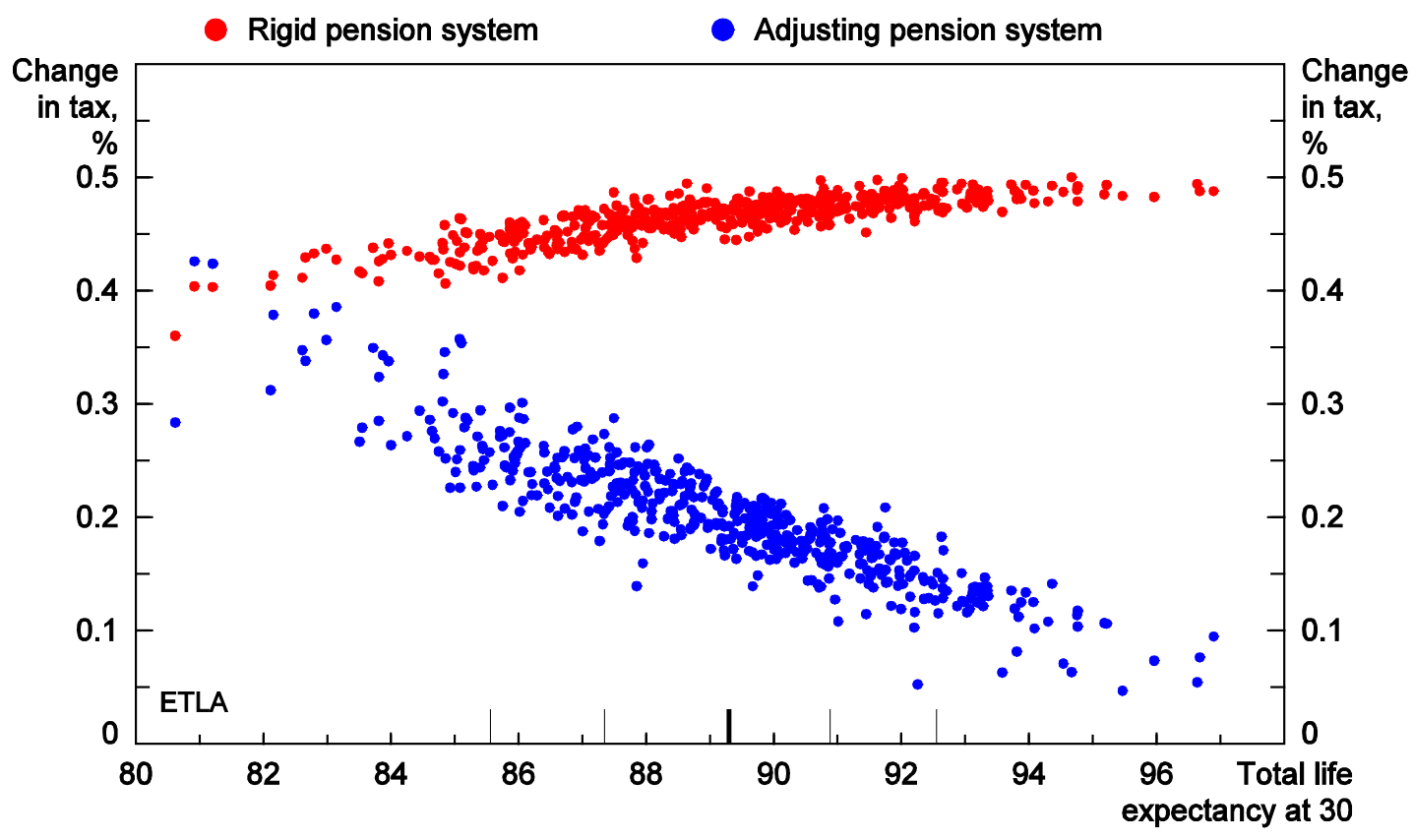


Figure 6. Tax switch effects on public expenditure/GDP in 2067 with varying longevity

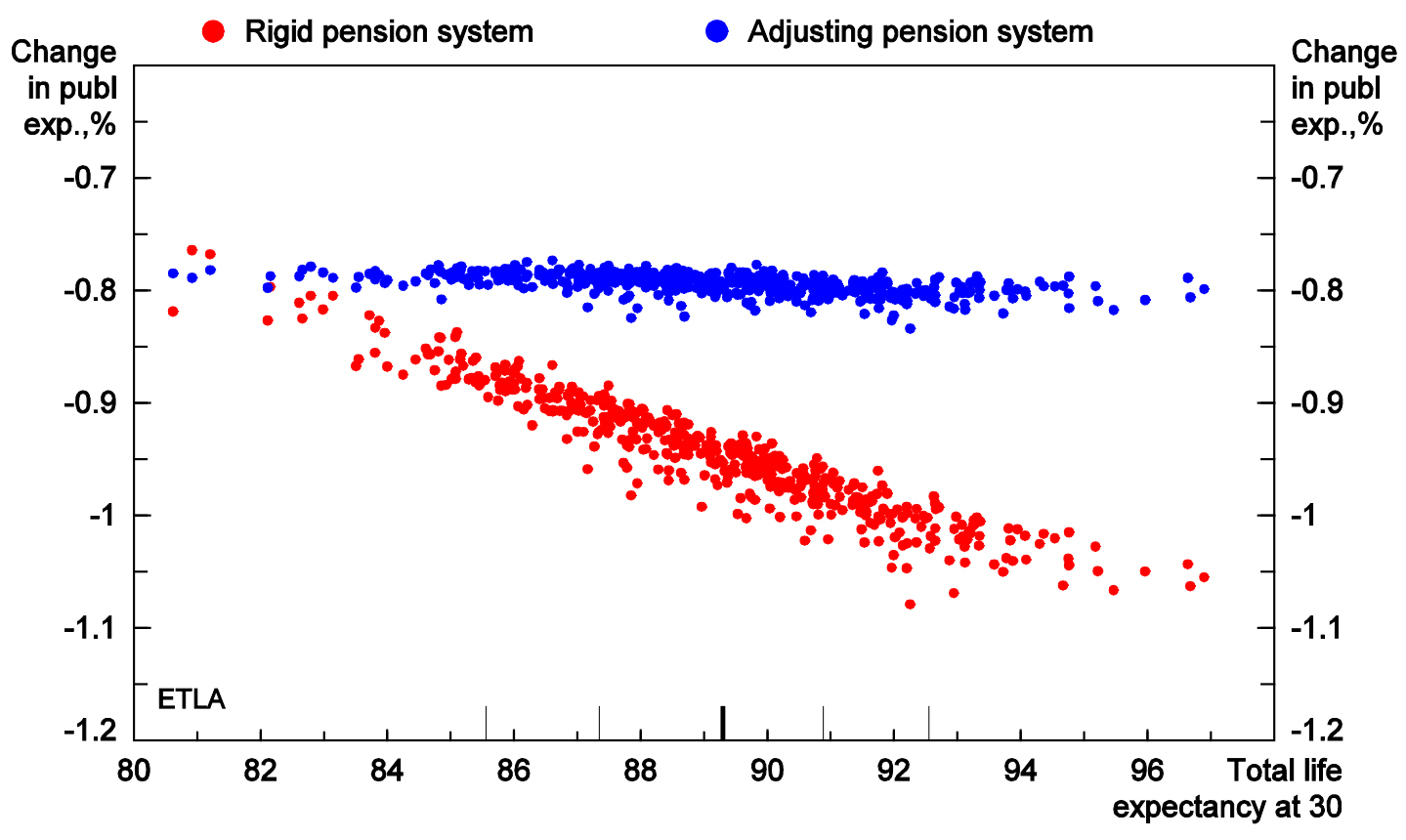

Table 2. Selected economic variables under different pension and tax systems, by life expectancy quartiles

\begin{tabular}{|c|c|c|c|c|c|c|c|c|}
\hline \multirow{2}{*}{$\begin{array}{l}\text { Total life expectancy } \\
\text { at } 30 \text { in } 2063 \text { (TLE) }\end{array}$} & \multicolumn{2}{|c|}{$\begin{array}{c}\mathrm{Q}_{1} \\
\mathrm{TLE}<87.3\end{array}$} & \multicolumn{2}{|c|}{$\begin{array}{c}\mathrm{Q}_{2} \\
87.3<\mathrm{TLE}<89.3\end{array}$} & \multicolumn{2}{|c|}{$\begin{array}{c}\mathrm{Q}_{3} \\
89.3<\mathrm{TLE}<90.9\end{array}$} & \multicolumn{2}{|c|}{$\begin{array}{c}\mathrm{Q}_{4} \\
90.9<\mathrm{TLE}\end{array}$} \\
\hline & Mean & Std & Mean & Std & Mean & Std & Mean & Std \\
\hline \multicolumn{9}{|c|}{ Pension expenditure/wage bill, \%, 2063-67 } \\
\hline Rigid scheme, EET & 34.07 & 1.338 & 36.42 & 0.744 & 37.80 & 0.696 & 39.64 & 1.019 \\
\hline Rigid scheme, TEE & 34.28 & 1.365 & 36.68 & 0.763 & 38.10 & 0.711 & 39.99 & 1.047 \\
\hline Adjusting scheme, EET & 28.63 & 0.602 & 28.45 & 0.300 & 28.29 & 0.280 & 28.14 & 0.425 \\
\hline Adjusting scheme, TEE & 28.75 & 0.608 & 28.58 & 0.307 & 28.42 & 0.287 & 28.27 & 0.436 \\
\hline Policy effects, Rigid & 0.22 & 0.030 & 0.27 & 0.022 & 0.30 & 0.019 & 0.35 & 0.031 \\
\hline Policy effects, Adjusting & 0.12 & 0.012 & 0.13 & 0.011 & 0.13 & 0.010 & 0.14 & 0.015 \\
\hline \multicolumn{9}{|c|}{ Pension contribution rate, $\%, 2063-67$} \\
\hline Rigid scheme, EET & 29.45 & 1.413 & 31.83 & 0.821 & 33.28 & 0.724 & 35.23 & 1.066 \\
\hline Rigid scheme, TEE & 29.63 & 1.430 & 32.04 & 0.834 & 33.51 & 0.735 & 35.50 & 1.087 \\
\hline Adjusting scheme, EET & 24.17 & 0.500 & 24.19 & 0.378 & 24.18 & 0.381 & 24.25 & 0.515 \\
\hline Adjusting scheme, TEE & 24.28 & 0.508 & 24.30 & 0.385 & 24.29 & 0.388 & 24.37 & 0.525 \\
\hline Policy effects, Rigid & 0.18 & 0.018 & 0.21 & 0.015 & 0.23 & 0.013 & 0.27 & 0.022 \\
\hline Policy effects, Adjusting & 0.11 & 0.009 & 0.12 & 0.008 & 0.12 & 0.008 & 0.12 & 0.011 \\
\hline \multicolumn{9}{|c|}{ Wage rate, 2063-67 $(2008-2012=1)$} \\
\hline Rigid scheme, EET & 1.037 & 0.006 & 1.032 & 0.005 & 1.030 & 0.005 & 1.030 & 0.005 \\
\hline Rigid scheme, TEE & 0.994 & 0.006 & 0.987 & 0.005 & 0.985 & 0.004 & 0.984 & 0.005 \\
\hline Adjusting scheme, EET & 1.045 & 0.008 & 1.037 & 0.006 & 1.032 & 0.006 & 1.027 & 0.007 \\
\hline Adjusting scheme, TEE & 1.004 & 0.008 & 0.996 & 0.006 & 0.991 & 0.006 & 0.986 & 0.007 \\
\hline Policy effects, Rigid & -4.15 & 0.095 & -4.30 & 0.057 & -4.39 & 0.050 & -4.51 & 0.063 \\
\hline
\end{tabular}




\begin{tabular}{|c|c|c|c|c|c|c|c|c|}
\hline Policy effects, Adjusting & -3.92 & 0.025 & -3.95 & 0.025 & -3.97 & 0.023 & -4.00 & 0.025 \\
\hline \multicolumn{9}{|c|}{ Labour supply, 2063-67 (2008-2012 = 1) } \\
\hline Rigid scheme, EET & 1.002 & 0.006 & 1.010 & 0.005 & 1.014 & 0.004 & 1.019 & 0.005 \\
\hline Rigid scheme, TEE & 0.993 & 0.006 & 1.000 & 0.005 & 1.004 & 0.004 & 1.008 & 0.005 \\
\hline Adjusting scheme, EET & 1.032 & 0.015 & 1.060 & 0.007 & 1.079 & 0.005 & 1.103 & 0.014 \\
\hline Adjusting scheme, TEE & 1.025 & 0.015 & 1.053 & 0.007 & 1.071 & 0.005 & 1.095 & 0.014 \\
\hline Policy effects, Rigid & -0.94 & 0.047 & -1.02 & 0.032 & -1.06 & 0.030 & -1.13 & 0.041 \\
\hline Policy effects, Adjusting & -0.70 & 0.042 & -0.69 & 0.030 & -0.68 & 0.029 & -0.67 & 0.042 \\
\hline \multicolumn{9}{|c|}{ Household wealth/GDP, \%, 2067} \\
\hline Rigid scheme, EET & 123.55 & 7.196 & 135.74 & 5.052 & 142.84 & 3.668 & 152.06 & 5.632 \\
\hline Rigid scheme, TEE & 87.02 & 5.491 & 96.35 & 4.025 & 101.62 & 2.888 & 108.41 & 4.333 \\
\hline Adjusting scheme, EET & 132.18 & 8.936 & 146.60 & 5.362 & 154.53 & 4.161 & 164.41 & 5.757 \\
\hline Adjusting scheme, TEE & 102.14 & 8.669 & 116.05 & 5.014 & 123.68 & 3.914 & 133.19 & 5.513 \\
\hline Policy effects, Rigid & -36.52 & 1.844 & -39.39 & 1.247 & -41.22 & 1.017 & -43.65 & 1.427 \\
\hline Policy effects, Adjusting & -30.04 & 0.383 & -30.55 & 0.388 & -30.85 & 0.286 & -31.22 & 0.285 \\
\hline \multicolumn{9}{|c|}{ Private consumption, 2063-67 (2008-2012 = 1) } \\
\hline Rigid scheme, EET & 0.978 & 0.014 & 0.955 & 0.009 & 0.941 & 0.008 & 0.922 & 0.011 \\
\hline Rigid scheme, TEE & 0.962 & 0.014 & 0.940 & 0.009 & 0.926 & 0.008 & 0.907 & 0.011 \\
\hline Adjusting scheme, EET & 1.001 & 0.007 & 0.990 & 0.007 & 0.983 & 0.006 & 0.974 & 0.007 \\
\hline Adjusting scheme, TEE & 0.984 & 0.007 & 0.973 & 0.007 & 0.967 & 0.006 & 0.957 & 0.007 \\
\hline Policy effects, Rigid & -1.65 & 0.049 & -1.62 & 0.050 & -1.61 & 0.038 & -1.59 & 0.036 \\
\hline Policy effects, Adjusting & -1.72 & 0.030 & -1.70 & 0.026 & -1.70 & 0.023 & -1.71 & 0.026 \\
\hline \multicolumn{9}{|c|}{ Consumer prices, 2063-67 (2008-2012 = 1) } \\
\hline Rigid scheme, EET & 0.988 & 0.002 & 0.989 & 0.002 & 0.990 & 0.002 & 0.991 & 0.002 \\
\hline Rigid scheme, TEE & 0.988 & 0.002 & 0.989 & 0.002 & 0.990 & 0.002 & 0.992 & 0.002 \\
\hline Adjusting scheme, EET & 0.984 & 0.002 & 0.981 & 0.002 & 0.979 & 0.001 & 0.977 & 0.002 \\
\hline Adjusting scheme, TEE & 0.983 & 0.002 & 0.980 & 0.001 & 0.978 & 0.001 & 0.976 & 0.002 \\
\hline Policy effects, Rigid & 0.00 & 0.010 & 0.02 & 0.008 & 0.03 & 0.007 & 0.04 & 0.011 \\
\hline Policy effects, Adjusting & -0.07 & 0.009 & -0.08 & 0.006 & -0.08 & 0.005 & -0.09 & 0.007 \\
\hline \multicolumn{9}{|c|}{ Total taxes/GDP, \%, 2063-67 } \\
\hline Rigid sche & 46.46 & 0.621 & 47.43 & 0.448 & 48.06 & & & 0.552 \\
\hline Rigid scheme, TEE & 46.90 & 0.628 & 47.89 & 0.446 & 48.54 & 0.393 & 49.47 & 0.555 \\
\hline Adjusting scheme, EET & 44.84 & 0.244 & 45.02 & 0.283 & 45.15 & 0.281 & 45.41 & 0.308 \\
\hline Adjusting scheme, TEE & 45.10 & 0.235 & 45.24 & 0.271 & 45.34 & 0.274 & 45.55 & 0.303 \\
\hline Policy effects, Rigid & 0.44 & 0.017 & 0.46 & 0.011 & 0.47 & 0.009 & 0.48 & 0.009 \\
\hline Policy effects, Adjusting & 0.26 & 0.046 & 0.22 & 0.025 & 0.18 & 0.019 & 0.14 & 0.031 \\
\hline \multicolumn{9}{|c|}{ Public expenditure/GDP, 2063-67 } \\
\hline Rigid scheme, EET & 40.36 & 0.714 & 41.43 & 0.555 & 42.16 & 0.498 & 43.24 & 0.672 \\
\hline Rigid scheme, TEE & 39.48 & 0.684 & 40.50 & 0.536 & 41.19 & 0.482 & 42.23 & 0.649 \\
\hline Adjusting scheme, EET & 38.42 & 0.295 & 38.49 & 0.341 & 38.57 & 0.338 & 38.80 & 0.370 \\
\hline Adjusting scheme, TEE & 37.63 & 0.290 & 37.70 & 0.333 & 37.78 & 0.331 & 38.00 & 0.363 \\
\hline Policy effects, Rigid & -0.88 & 0.032 & -0.93 & 0.020 & -0.96 & 0.018 & -1.01 & 0.025 \\
\hline Policy effects, Adjusting & -0.79 & 0.006 & -0.79 & 0.008 & -0.80 & 0.008 & -0.80 & 0.009 \\
\hline \multicolumn{9}{|l|}{ Sustainability gap, \% } \\
\hline Rigid scheme, EET & 2.74 & 0.359 & 3.28 & 0.270 & 3.65 & 0.242 & 4.173 & 0.314 \\
\hline Rigid scheme, TEE & 1.89 & 0.341 & 2.40 & 0.258 & 2.75 & 0.231 & 3.248 & 0.299 \\
\hline Adjusting scheme, EET & 1.06 & 0.094 & 1.03 & 0.104 & 1.02 & 0.094 & 1.04 & 0.089 \\
\hline
\end{tabular}




\begin{tabular}{|l|rr|rr|rr|rr|} 
Adjusting scheme, TEE & 0.29 & 0.090 & 0.26 & 0.101 & 0.26 & 0.091 & 0.28 & 0.085 \\
Policy effects, Rigid & -0.85 & 0.018 & -0.88 & 0.012 & -0.90 & 0.011 & -0.92 & 0.014 \\
Policy effects, Adjusting & -0.77 & 0.005 & -0.76 & 0.004 & -0.76 & 0.004 & -0.76 & 0.005 \\
\hline
\end{tabular}

\section{Patterns in variation}

Table 2 also includes standard deviations of variables in each longevity quadrant. Some patterns can be observed.

First, variation is often larger in the first and fourth quadrants (Q1 and Q4) than in the middle quadrants (Q2 and Q3). This is due to the property of the stochastic mortality simulations that longevity itself varies less in the middle quadrants. The ranges of Q2 and Q3 are two years and 1,5 years respectively, whereas the range of Q1 is about seven years (see e.g. Figure 2) and the range of Q4 is six years. These differences are reflected also in the economic variables.

Second, variation is often larger in the first quadrant (Q1) than in the fourth quadrant (Q4). Again, longevity itself varies more in the first quadrant, and generally variation is larger at lower life expectancies (see Figure 1). This is explained by the fact that the longevity measure is a multiplicative statistic of survival values that are between zero and one. The larger variation amongst low life expectancies can be seen also in Figures 4 and 5 , where it generates more variation in the tax regime shift results in the scheme which includes life expectancy related adjustment rules.

Third, the variation in the effects of the tax switch is larger in the Adjusting pension scheme than in the Rigid pension scheme (the only exception in Table 2 is household wealth). Varying work careers and/or the presence of longevity adjustment of pension benefits must be the reasons, as otherwise the Rigid and the Adjusting cases are the same. Why do they bring such differences? A partial answer is that the total variations in policy effects, across all quadrants, are closer together than the within-quadrant variations. The variations in labour supply, wage rate and total taxes actually become much closer together. The variation in policy effects on household wealth, on the other hand, becomes much larger in the Rigid scheme than in the Adjusting scheme. One could say that varying work careers and longevity adjustment of benefits just distribute the effects differently. This is not a full explanation; more work is needed here.

\section{Generational effects}

As an intergenerational measure of policy effects, we use relative compensated variations for each cohort. They are calculated as $100(\ln E(c)-\ln E(s))$, where $E$ denotes discounted consumption expenditure during the rest of lifetime, $s$ refers to simulation run and $c$ is consumption necessary to achieve the baseline utility at simulation prices.

Two main factors causing the losses are the decline in wages, both gross and net, and labour supply. The gains come from decreased lump-sum taxes.

As noted earlier, gross wages decline almost immediately to a new lower level. The decline is real, as consumer prices remain practically unchanged. Furthermore, wage income is effectively taxed with a higher rate, since 
employee's contributions cease to be deductible. Labour supply declines gradually, reflecting how the weakening incentives affect a larger share of working careers as time progresses.

The distribution of the gains depends on how the improvement in the central government's finances is used. In the simulations described above it was used to decrease lump-sum taxes. The decrease is shared every period equally to each household. This assumption causes the rather significant generational redistribution that Table 3 reveals. The government could of course choose some other rule to smooth the welfare outcomes, but in any case the losses would dominate.

Table 3. Relative gains and losses from the pension tax switch

\begin{tabular}{|l|r|r|r|r|r|r|r|r|}
\hline $\begin{array}{l}\text { Birth year of } \\
\text { the cohort }\end{array}$ & 1933 & 1953 & 1973 & 1993 & 2013 & 2033 & $\begin{array}{l}\text { Long } \\
\text { run }\end{array}$ \\
\hline Rigid scheme \\
\hline $90 \%$ & 0.7 & 0.0 & -0.5 & 2.0 & 0.5 & -1.1 & -4.1 \\
\hline Md. & 0.6 & -0.1 & -0.6 & 1.5 & 0.3 & -1.3 & -4.7 \\
\hline $10 \%$ & 0.5 & -0.2 & -0.8 & 1.1 & 0.0 & -1.5 & -5.1 \\
\hline Adjusting scheme \\
\hline 90 & 0.5 & -0.5 & -1.1 & 1.0 & -0.2 & -1.2 & -2.6 \\
\hline Md. & 0.5 & -0.6 & -1.2 & 0.8 & -0.3 & -1.3 & -2.8 \\
\hline $10 \%$ & 0.5 & -0.6 & -1.3 & 0.7 & -0.4 & -1.3 & -2.9 \\
\hline
\end{tabular}

Compensated variation as $\%$ of discounted consumption expenditure during remaining lifetime.

For those already retired the lump-sum tax effects dominate. The decline in wages lowers pension benefits which are partly indexed to wages, but this effect is rather small. On the other hand, lump-sum effect is initially also small, so the welfare effects remain small.

Those already in the work life usually suffer a little. Wage decline hits them fully, and lump-sum effects do not compensate enough.

Cohorts that enter the labour force when the tax switch is made, or 5 to 10 years after, gain a little. They benefit from lump-sum effects that grow during their lifetime, and the tax increase does not hit them fully in their early working years. In the Rigid scheme the biggest lifetime consumption increases are around $1.5 \%$. In the Adjusting scheme the gains are smaller. Future generations lose from the reform, and the losses grow from one generation to the next. In the long run the losses are around $5 \%$ in the Rigid scheme and close to $3 \%$ in the Adjusting scheme.

In the Rigid scheme the losses are smaller and gains bigger with longer lifetimes. In the Adjusting scheme the differences are negligible.

\section{Effects on fiscal sustainability}

The sustainability gap estimates in Table 2 are based 100-year evaluations. We note that the gap is larger under the Rigid scheme than under the Adjusting scheme. This is easily understandable, as in the latter scheme monthly pension benefits are adjusted downwards if longevity increases, and work careers also become longer, bringing more tax revenues. In the Rigid scheme none of this happens. The gap also grows more with longevity under Rigid scheme than under Adjusting scheme, for the same reasons that affect the average gap size. The 
effects of the tax switch grow very slightly with longevity in the Rigid scheme. There is no clear pattern related to longevity in the Adjusting scheme, but on average the effects are slightly smaller than in the Rigid scheme.

\section{CONCLUSIONS}

We have aimed at limiting the problematic consequences of continuously increasing longevity to public finances by introducing a tax regime shift from EET to TEE in the earnings-related first pillar pension scheme. A shift to TEE taxation of pensions broadens the tax base both in wage income and corporate income taxation by abolishing the entitlement to deduct the employees' and employers' contributions. It also abolishes taxation of pensions. The net effect is expected to increase tax revenues in progressive taxation due to the differences in timing and the tax rates used.

We have studied the connections between pension tax regimes, longevity, and pension policies using the Finnish earnings-related pension scheme as an example. Uncertainty in longevity is considered using large amount of sample paths (500) from a stochastic mortality projection as inputs in an economic simulation model, which is an open economy version of the Auerbach-Kotlikoff OLG model. We have three levels of results: the reactions of the economy to increasing longevity, how longevity and the two pension schemes interact and the outcomes of the tax regime shift.

It turns out that abolishing deductibility of pension contributions have strong indirect effects on tax bases. Since the Finnish earnings-related pension scheme in mainly financed by employers' contributions, the reaction of the firms to the increase in labour costs dominate the outcomes. Wage rates and demand for labour fall which decreases income and consumption. But the total tax rate increase due to tightened taxation of profits and labour income. Moreover, lower wages decrease public sector wages and income transfers indexed to wages. Therefore the regime shift improves public finances as expected, but at the expense of less efficient tax structure and lower consumption.

The analysis is complicated by the fact that several first pillar pension schemes have already adopted rules, which adjust pensions or eligibility ages of the pension scheme to life expectancy. Therefore we considered two extremes. Rigid pension scheme is one where there is neither longevity adjustment of benefits nor higher eligibility age for pensions when people live longer. In this scheme longer lifetimes will increase pension expenditure and contribution rates and reduce tax revenues. Adjusting pension scheme has both longevity adjustment of benefits and longer work careers which are partially due to a link between retirement age and longevity. Increasing longevity will in fact slightly decline pension expenditure relative to wages. The net tax revenues related to the pension scheme increase.

The effects of switching from EET to TEE regime change in a different way when longevity changes. If longevity affects pension expenditure or pension financing, as it does under the Rigid pension scheme, the effects of the tax switch on wages, employment and household wealth are stronger than in the Adjusting scheme, but they also become somewhat larger the more longevity increase. 
If longevity does not affect pension expenditure or pension financing much, due to e.g. longevity adjustment of pensions, or longer work careers as in the Adjusting scheme, the effects of the tax switch do not change much with changes in longevity. In this automatically adjusting pension scheme, the tax regime shift is not so efficient, but more importantly, not so necessary either. 


\section{REFERENCES}

Alho, Juha M., 1990. "Stochastic methods in population forecasting", International Journal of Forecasting 6, 521-530.

Alho, Juha M., 2002. "The population of Finland in 2050 and beyond", The Research Institute of the Finnish Economy, Discussion Papers No. 826.

Alho, Juha M., Svend E. Hougaard Jensen and Jukka Lassila, (eds). 2008. "Uncertain Demographics and Fiscal Sustainability", Cambridge University Press (2008).

Alho, Juha M., and Spencer, Bruce D., 2005. "Statistical Demography and Forecasting", New York : Springer. Auerbach, Alan J. and Lawrence J. Kotlikoff, 1987. "Dynamic Fiscal Policy", Cambridge, Cambridge University Press.

Chen, Damiaan H.J., Roel Beetsma, Eduard Ponds and Ward E. Romp, 2014. "Intergenerational Risk-Sharing through Funded Pensions and Public Debt", CESifo Working Paper No. 4624, February 2014.

Diamond, Peter, 2009. "Taxes and pensions", Center for Retirement Research at Boston College, CRR WP 200912.

Fehr, Hans, Christian Habermann and Fabian Kindermann, 2008. "Tax-Favored Retirement Accounts: Are they Efficient in Increasing Savings and Growth?," FinanzArchiv: Public Finance Analysis, Mohr Siebeck, Tübingen, 64(2), 171-198, June.

Fehr, Hans, Manuel Kallweit and Fabian Kindermann, 2012. "Pension reform with variable retirement age: a simulation analysis for Germany", Journal of Pension Economics and Finance, Cambridge University Press, 11(03), 389-417, July.

Kudrna, George and Alan Woodland, 2012. "Progressive Tax Changes to Private Pensions in a Life-Cycle Framework," Working Papers 201209, ARC Centre of Excellence in Population Ageing Research (CEPAR), Australian School of Business, University of New South Wales.

Lassila, Jukka and Tarmo Valkonen, 2007. "The Finnish pension reform of 2005", Geneva Papers on Risk and Insurance 32(1), $75-94$.

Lassila, Jukka, 2014. "Linking retirement age to longevity: economic assessment", In Lassila Määttänen and Valkonen, 2014.

Lassila, Jukka, Niku Määttänen and Tarmo Valkonen, 2014. "Linking retirement age to life expectancy - what happens to working lives and income distribution?" ETLA B 260. Taloustieto.

Lee, Ronald D. and Timothy Miller, 2001. "Estimating the performance of the Lee-Carter method for forecasting mortality", Demography 38, 537-549. 
Määttänen, Niku, 2014. “Pension reforms, careers and income distribution”, In Lassila Määttänen and Valkonen, 2014.

Sánchez Martín, Alfonso R., 2010. "Endogenous retirement and public pension scheme reform in Spain", Economic Modelling, Elsevier, 27(1), 336-349.

SOU, 2013. "Åtgärder för ett längre arbetsliv", Slutbetänkande av Pensionsåldersutredningen (SOU 2013:35).

Staubli, Stefan and Zweimüller, Josef, 2013. "Does raising the early retirement age increase employment of older workers?", Journal of Public Economics, Elsevier, vol. 108(C), 17-32.

\section{APPENDIX 1: THE FINNISH EARNINGS-RELATED PENSION SCHEME}

The earnings-related pension scheme aims to provide sufficient retirement income to cover consumption comparable to levels enjoyed during working years and to current workers' consumption. It covers risks related to old age, disability and death of family earners. In cases where the earnings-related pension is absent or insufficient, the national pension guarantees a minimum income. Both of these first-pillar schemes are mandatory. Voluntary pensions are still of minor importance in Finland but are becoming more common. Below we describe the private sector earnings-related scheme. Public sector pension schemes are becoming similar, except that funding is different and there are long transition periods from old benefit rules.

The scheme is described as it is after the 2005 reform. A new reform will take place in 2017, but it is not essential for this study.

\section{Benefits}

The pensions can be thought of as consisting of both disability pensions and old-age pensions. Every year's earnings and accrual rates directly affect the future pension. The accrual rate is $1.5 \%$ per year between the ages of 18 and 53 and $1.9 \%$ between the ages 53 and 62 . Between the ages 63 and 68 the accrual is $4.5 \%$ per year, aiming to reward later retirement in a cost-neutral way.

Both pension rights and benefits are index linked, with 80-20 weights on wages and consumer prices respectively during working years and 20-80 weights after retirement, irrespective of retirement age. In the model, function $I(t, u, \lambda)$ states that the change in wages $w$ from period $t$ to period $u$ is weighted by $\lambda$ and the change in consumer prices $p$ is weighted by $1-\lambda$. Employee's contributions $e$ are deducted from wages in this calculation. 


$$
I(t, u, \lambda)=\left(\frac{w(u)(1-e(u))}{w(t)(1-e(t))}\right)^{\lambda}\left(\frac{p(u)}{p(t)}\right)^{1-\lambda}
$$

We denote the accruals with $k(x)$ where $x$ refers to age. If retirement occurs due to disability, the pensioner is compensated for lost future accruals. The compensation depends on the age at the time of the disability event; we denote it by $f(z)$ where $z$ refers to the age during the last working period. After receiving the disability pension for five years there is a one-time level increase in the pension. This increase is $21 \%$ for a person aged 26 or less, and smaller for older persons, so that those aged 56 or more get no increase. This feature is denoted by $a(x, z)$. Thus the pension benefit $b$, without longevity adjustment, for an individual $i$ in age group $\mathrm{x}$ who retired at age $z+1$ and had earned wage incomes denoted by $y$ is as follows.

(0)

$$
\begin{aligned}
b_{i}(t, x, z)= & a(x, z) \sum_{s=1}^{z} k(s) y_{i}(t-s)(1-e(t-s)) I(t-s, t-x+z, 0.8) I(t-x+z, t, 0.2) \\
& +a(x, z) f(z) y_{i}(t-x+z)(1-e(t-x+z)) I(t-x+z, t, 0.2)
\end{aligned}
$$

where $x>z$.

\section{Longevity adjustment}

The pensions are adjusted for increasing life expectancy simply by taking the increasing longevity into account in the value of the annuity. The adjustment coefficient is a ratio of two present values of a unit pension, calculated at two different periods. The present value of a unit pension, which begins in period $t$ and is calculated forward from age 62 , is as follows.

$$
A(t, 62)=\sum_{s=63}^{100} S(t-1,62, s) /(1.02)^{s-62}
$$

The present value of a unit pension is a discounted sum of terms generated during various retirement years. The terms have two parts. The first term, $S$, expresses the survival probability from age 62 to age $s$, and the first subscript of the term demonstrates that the probability is evaluated using information available in period $t$, when the latest the observed mortalities are from period $t$-1. The survival probabilities are actually five-year moving averages. The second term is the discount factor where the discount rate is $2 \%$ per year. In the model individuals die at the age of 100 at the latest. 
The pension of a person born in period $t-62$ is multiplied by the longevity adjustment coefficient $E(t, 62)$ after age 62 . The coefficient is a ratio of two $A$-terms as follows.

(2)

$$
E(t, 62)=A(2009,62) / A(t, 62)
$$

\section{Prefunding on the individual level}

The Finnish earnings-related scheme has collected substantial funds to smoothen the contribution increases due to population ageing in the future. Funding is collective but based on individual pension rights. Individual pension benefits do not depend on the existence or yield of funds. Funds only affect contributions. When a person receives a pension after the age of 65 , his/her funds are used to pay that part of the pension benefit that was prefunded. The rest comes from the PAYG part, the so-called pooled component in the contribution rate.

Equation (2) describes new funding for an individual $i$. A share $g$ of the present value of the pension right accruing in period $t$ to workers in the age range 18 - 54 is put in the funds. The present value includes all oldage pension years, from 65 to a maximum age assumed to be 100. The labour income $y$ creates a pension right for each year in old age. Discounting includes both the so-called fund rate of interest $q$, which is administratively set, and survival probabilities $S$. For prefunding purposes, the magnitude of the pension right is evaluated ignoring all future changes due to wage or price developments. Thus the value of the right is simply $k$ times the labour income, without the employee contribution part, for each retirement year.

$$
h_{i}(t, x)=g \sum_{s=65}^{100} k(x) y_{i}(t)(1-e(t)) S(t-1, x, s) /(1+q)^{s-x}
$$

where $x=18, \ldots, 54$.

Equation (2) states that for a retired person the amounts prefunded earlier (when the current pensioner was between the ages of 18 and 54) for period $t$ 's pension, with the interest accrued to them with rate $r$ and leading to a total amount $v$, is used to pay a part of the person's pension. The interest accrued is assumed here to be constant for a simpler exposition. In practice it follows approximately the average market yield plus a margin, and must not be lower than the fund rate in equation (2). 
(2) $v_{i}(t, x)=\sum_{s=18}^{54} g k(s) y_{i}(t-x+s)(1-e(t-x+s)) S(t-x+s-1, x-s, x)(1+q)^{s-x}(1+r)^{x-s}$

where $x=65, \ldots, 100$.

\section{Contribution and replacement rates}

The equations (2) and (2) are important for the aggregate dynamics of the pension scheme, especially for the level and time path of the contribution rates.

Let $n(t, x)$ be the number of workers and $\bar{h}(t, x)$ the average amount of new funding per worker in age $x$ in period $t$. The total amount of new funding in period $t$ is obtained by multiplying the average individual funding in age group $x$ by the number of workers in the age group, and summing over all age groups where funding takes place. Analogously, $m(t, x)$ is the number of retired persons and $\bar{v}(t, x)$ is the average amount withdrawn from the funds per retiree in each age group, and the total amount withdrawn from the funds is obtained by multiplying the average withdrawals by the number of retirees and summing over relevant age groups. Three other aggregates are defined in a similar fashion: the total wage bill from which the pension contributions are collected, denoting the average wage income at age $x$ by $\bar{y}(t, x)$, the total amount of earnings-related pension expenditure, denoting the average pension of retired persons by $\bar{b}(t, x)$ and the total amount of other transfers from the pension sector, denoting the average transfer per person by $\bar{s}(t, x)$.

The time path of the contribution rates is given by equation (2). Besides employees, employers must also pay contributions, which we denote by $c(t)$, based on the wage bill. The left-hand side of the equation is the total amount of contributions. That must be sufficient to cover that part of the pension expenditure (first term on the right-hand side) that does not come from withdrawals from the funds (second term), plus new funding (third term), plus transfers (the final term).

$$
\begin{aligned}
{[c(t)+e(t)] \sum_{x=18}^{64} n(t, x) \bar{y}(t, x) } & =\sum_{x=18}^{100} m(t, x) \bar{b}(t, x)-\sum_{x=65}^{100} m(t, x) \bar{v}(t, x) \\
& +\sum_{x=18}^{54} n(t, x) \bar{h}(t, x)+\sum_{x=18}^{100}[n(t, x)+m(t, x)] \bar{s}(t, x)
\end{aligned}
$$

When we speak about the contribution rate we mean the sum of employer and employee contribution rates, where the latter is weighted from the age-dependent rates with corresponding revenue shares. 


\section{APPENDix 2. The Rigid AND THE AdJUSTING PENSION SCHEME}

The Rigid pension scheme is the Finnish scheme described above, except that the longevity adjustment is not applied. Another noteworthy feature is that earliest eligibility age for old-age pension is kept constant, and average effective retirement age does not change even if people live longer.

In the Adjusting pension scheme longevity adjustment is applied but it is mitigated, cutting monthly pensions to a lesser degree than the current longevity indicator does. The mitigated longevity indicator is also applied to the earned part of the disability pension.

Besides longevity adjustment, the Adjusting pension scheme reacts to longevity shocks with retirement age. The earliest eligibility age for old-age pension is tied to adulthood life expectancy (adulthood begins at age 18) so that the retirement age divides the adulthood life expectancy in the same proportion each year. When the linking is introduced, the retirement age is raised by 10 months. If the life expectancy of a 63-year-old grows by an ample six years over a period of 50 years, the retirement age is raised by four years as a result of making this link. The earliest eligibility age for part-time pension and the unemployment pathway to retirement are raised in the same manner. If a person continues to work past the earliest eligibility age for old-age retirement limit, pension will accrue at $1.9 \%$ of earnings. The start year of the $1.9 \%$ accrual rate will change from the current 53 years by $3 / 4$ of a year for each year of change in retirement age.

Linking retirement age to life expectancy affects the length of working lives. Based on the model used by Määttänen (2014), raising the eligibility ages of the pensionable age, the unemployment pathway and the parttime pension by two years would extend working lives by 7 months. These relations, from life expectancy to earliest eligibility age and from the eligibility age to working lives, are used in the stochastic simulations. Extending working lives are included in the OLG model exogenously, starting in 2018 through the pensioner proportion, since the model does not contain pensionable age as a variable. For a more detailed description, see Lassila (2014).

Table 4. Selected economic variables under different pension and tax schemes, by life expectancy quartiles

\begin{tabular}{|c|c|c|c|c|c|c|c|c|}
\hline \multirow{2}{*}{$\begin{array}{l}\text { Total life expectancy } \\
\text { at } 30 \text { in } 2063 \text { (TLE) }\end{array}$} & \multicolumn{2}{|c|}{$\begin{array}{c}\mathrm{Q}_{1} \\
\mathrm{TLE}<87.3\end{array}$} & \multicolumn{2}{|c|}{$\begin{array}{c}\mathrm{Q}_{2} \\
87.3<\mathrm{TLE}<89.3\end{array}$} & \multicolumn{2}{|c|}{$\begin{array}{c}\mathrm{Q}_{3} \\
89.3<\mathrm{TLE}<90.9\end{array}$} & \multicolumn{2}{|c|}{$\begin{array}{c}\mathrm{Q}_{4} \\
90.9<\mathrm{TLE}\end{array}$} \\
\hline & Mean & Std & Mean & Std & Mean & Std & Mean & Std \\
\hline \multicolumn{9}{|c|}{ Pension expenditure/wage bill, \%, 2033-37 } \\
\hline Rigid scheme, EET & 34.03 & 0.723 & 34.65 & 0.661 & 35.12 & 0.636 & 35.79 & 0.609 \\
\hline Rigid scheme, TEE & 34.47 & 0.758 & 35.12 & 0.693 & 35.63 & 0.667 & 36.34 & 0.640 \\
\hline Adjusting scheme, EET & 31.30 & 0.341 & 30.85 & 0.244 & 30.65 & 0.256 & 30.37 & 0.326 \\
\hline Adjusting scheme, TEE & 31.67 & 0.349 & 31.22 & 0.252 & 31.03 & 0.270 & 30.76 & 0.343 \\
\hline Policy effects, Rigid & 0.44 & 0.037 & 0.47 & 0.034 & 0.50 & 0.032 & 0.54 & 0.032 \\
\hline Policy effects, Adjusting & 0.37 & 0.023 & 0.37 & 0.021 & 0.38 & 0.023 & 0.39 & 0.024 \\
\hline \multicolumn{9}{|c|}{ Pension contribution rate, $\%, 2033-37$} \\
\hline Rigid scheme, EET & 29.30 & 0.881 & 30.18 & 0.751 & 30.82 & 0.712 & 31.68 & 0.728 \\
\hline
\end{tabular}




\begin{tabular}{|c|c|c|c|c|c|c|c|c|}
\hline Rigid scheme, TEE & 29.36 & 0.910 & 30.27 & 0.779 & 30.93 & 0.737 & 31.83 & 0.755 \\
\hline Adjusting scheme, EET & 26.58 & 0.565 & 26.24 & 0.445 & 26.18 & 0.494 & 26.03 & 0.625 \\
\hline Adjusting scheme, TEE & 26.60 & 0.578 & 26.26 & 0.457 & 26.22 & 0.510 & 26.08 & 0.641 \\
\hline Policy effects, Rigid & 0.06 & 0.032 & 0.09 & 0.029 & 0.12 & 0.027 & 0.15 & 0.028 \\
\hline Policy effects, Adjusting & 0.02 & 0.023 & 0.02 & 0.021 & 0.04 & 0.022 & 0.05 & 0.022 \\
\hline \multicolumn{9}{|c|}{ Wage rate, $2033-37(2008-2012=1)$} \\
\hline Rigid scheme, EET & 1.060 & 0.011 & 1.044 & 0.007 & 1.035 & 0.007 & 1.023 & 0.009 \\
\hline Rigid scheme, TEE & 1.011 & 0.011 & 0.995 & 0.007 & 0.986 & 0.007 & 0.974 & 0.009 \\
\hline Adjusting scheme, EET & 1.061 & 0.013 & 1.044 & 0.009 & 1.035 & 0.009 & 1.022 & 0.011 \\
\hline Adjusting scheme, TEE & 1.012 & 0.013 & 0.996 & 0.009 & 0.988 & 0.009 & 0.975 & 0.010 \\
\hline Policy effects, Rigid & -4.67 & 0.069 & -4.71 & 0.066 & -4.74 & 0.061 & -4.79 & 0.057 \\
\hline Policy effects, Adjusting & -4.61 & 0.049 & -4.60 & 0.045 & -4.59 & 0.046 & -4.59 & 0.050 \\
\hline \multicolumn{9}{|c|}{ Labour supply, 2033-37 (2008-2012 = 1) } \\
\hline Rigid scheme, EET & 0.985 & 0.004 & 0.994 & 0.003 & 0.998 & 0.003 & 1.004 & 0.004 \\
\hline Rigid scheme, TEE & 0.983 & 0.004 & 0.991 & 0.003 & 0.996 & 0.003 & 1.002 & 0.004 \\
\hline Adjusting scheme, EET & 1.001 & 0.012 & 1.018 & 0.009 & 1.029 & 0.008 & 1.044 & 0.011 \\
\hline Adjusting scheme, TEE & 0.999 & 0.012 & 1.017 & 0.009 & 1.028 & 0.008 & 1.044 & 0.011 \\
\hline Policy effects, Rigid & -0.23 & 0.013 & -0.24 & 0.012 & -0.24 & 0.011 & -0.25 & 0.011 \\
\hline Policy effects, Adjusting & -0.11 & 0.029 & -0.09 & 0.021 & -0.08 & 0.018 & -0.07 & 0.020 \\
\hline \multicolumn{9}{|c|}{ Household wealth/GDP, \%, 2037} \\
\hline Rigid scheme, EET & 115.28 & 7.610 & 127.00 & 5.381 & 134.96 & 4.845 & 145.78 & 6.738 \\
\hline Rigid scheme, TEE & 100.34 & 7.026 & 111.06 & 4.987 & 118.38 & 4.503 & 128.31 & 6.223 \\
\hline Adjusting scheme, EET & 119.07 & 8.314 & 130.97 & 5.826 & 138.70 & 5.287 & 149.13 & 6.727 \\
\hline Adjusting scheme, TEE & 106.49 & 8.435 & 118.41 & 5.831 & 126.14 & 5.299 & 136.55 & 6.715 \\
\hline Policy effects, Rigid & -14.94 & 0.619 & -15.94 & 0.437 & -16.58 & 0.372 & -17.47 & 0.536 \\
\hline Policy effects, Adjusting & -12.59 & 0.234 & -12.57 & 0.196 & -12.56 & 0.158 & -12.58 & 0.160 \\
\hline \multicolumn{9}{|c|}{ Private consumption, 2033-37 $(2008-2012=1)$} \\
\hline Rigid scheme, EET & 0.998 & 0.009 & 0.986 & 0.007 & 0.978 & 0.007 & 0.967 & 0.007 \\
\hline Rigid scheme, TEE & 0.988 & 0.008 & 0.978 & 0.007 & 0.971 & 0.006 & 0.961 & 0.007 \\
\hline Adjusting scheme, EET & 1.007 & 0.006 & 1.001 & 0.005 & 0.997 & 0.005 & 0.991 & 0.005 \\
\hline Adjusting scheme, TEE & 0.994 & 0.006 & 0.989 & 0.005 & 0.985 & 0.005 & 0.980 & 0.005 \\
\hline Policy effects, Rigid & -1.00 & 0.081 & -0.85 & 0.055 & -0.76 & 0.047 & -0.64 & 0.075 \\
\hline Policy effects, Adjusting & -1.24 & 0.023 & -1.22 & 0.022 & -1.21 & 0.021 & -1.19 & 0.023 \\
\hline \multicolumn{9}{|c|}{ Consumer prices, 2033-37 (2008-2012 = 1) } \\
\hline Rigid scheme, EET & 0.997 & 0.002 & 0.993 & 0.001 & 0.992 & 0.001 & 0.989 & 0.002 \\
\hline Rigid scheme, TEE & 0.995 & 0.002 & 0.992 & 0.001 & 0.991 & 0.001 & 0.988 & 0.002 \\
\hline Adjusting scheme, EET & 0.995 & 0.003 & 0.991 & 0.002 & 0.989 & 0.002 & 0.986 & 0.002 \\
\hline Adjusting scheme, TEE & 0.993 & 0.003 & 0.989 & 0.002 & 0.987 & 0.002 & 0.984 & 0.002 \\
\hline Policy effects, Rigid & -0.13 & 0.011 & -0.11 & 0.007 & -0.10 & 0.006 & -0.09 & 0.009 \\
\hline Policy effects, Adjusting & -0.19 & 0.007 & -0.19 & 0.006 & -0.19 & 0.005 & -0.19 & 0.005 \\
\hline \multicolumn{9}{|c|}{ Total taxes/GDP, \%, 2033-37 } \\
\hline Rigid scheme, EET & 47.59 & 0.272 & 47.60 & 0.280 & 47.68 & 0.271 & 47.75 & 0.250 \\
\hline Rigid scheme, TEE & 47.30 & 0.275 & 47.33 & 0.282 & 47.42 & 0.271 & 47.51 & 0.251 \\
\hline Adjusting scheme, EET & 46.76 & 0.367 & 46.37 & 0.275 & 46.21 & 0.290 & 45.94 & 0.343 \\
\hline Adjusting scheme, TEE & 46.41 & 0.369 & 46.02 & 0.274 & 45.87 & 0.291 & 45.61 & 0.344 \\
\hline Policy effects, Rigid & -0.29 & 0.013 & -0.27 & 0.009 & -0.26 & 0.008 & -0.24 & 0.011 \\
\hline Policy effects, Adjusting & -0.35 & 0.02 & -0.35 & 0.02 & -0.34 & 0.02 & -0.34 & 0.02 \\
\hline
\end{tabular}


Public expenditure/GDP, 2033-37

\begin{tabular}{|l|l}
\hline Rigid scheme, EET & 42.07 \\
\hline
\end{tabular}

Rigid scheme, TEE

$\begin{array}{ll}41.05 & 0.308\end{array}$

41.90

41.12

0.499

40.87

Adjusting scheme, EET

Adjusting scheme, TEE

$\begin{array}{ll}40.15 & 0.484\end{array}$

$-1.02 \quad 0.016$

40.52

0.306

41.86

40.83

0.314

41.80

0.300

Policy effects, Rigid

$-0.97 \quad 0.017$

39.56

$0.356 \quad 40.21$

0.302

$\begin{array}{ll}40.76 & 0.291\end{array}$

Policy effects, Adjusting

$\begin{array}{rr}-1.03 & 0.016 \\ -0.95 & 0.014\end{array}$

39.27

$-1.03$

0.354

$39.76 \quad 0.427$

$38.83 \quad 0.412$

$-0.94$

0.015

$-1.04$

$-0.93 \quad 0.017$ 